\title{
Retraction Note to: Repetitive extragenic palindromic PCR (REP-PCR) as a method used for bulking process detection in activated sludge
}

Dagna Sołtysik • Ilona Bednarek • Tomasz Loch • Sabina Gałka • Daniel Sypniewski

Published online: 24 March 2013

(C) Springer Science+Business Media Dordrecht 2013

Retraction to: Environ Monit Assess:

Volume 176 (1-4):343-354

DOI 10.1007/s10661-010-1587-0

This article has been retracted due to copyright violation.

The online version of the original article can be found at http:// dx.doi.org/10.1007/s10661-010-1587-0.

D. Sołtysik $\cdot$ I. Bednarek $(\bowtie) \cdot$ T. Loch $\cdot$ S. Gałka •

D. Sypniewski

Department of Biotechnology and Genetic Engineering,

Medical University of Silesia,

Narcyzów 1 Street,

41-200 Sosnowiec, Poland

e-mail: dribednarek@sum.edu.pl 